\title{
Phosphoinositol Kinase Family Gene
}

National Cancer Institute

\section{Source}

National Cancer Institute. Phosphoinositol Kinase Family Gene. NCI Thesaurus. Code C26072.

Human Phosphoinositol Kinase Family Genes encode Phosphoinositol Kinases, enzymes that phosphorylate at various positions the inositol group in membrane-bound phosphatidylinositol, often in response to extracellular signals through G-Protein Coupled Receptors or Receptor Tyrosine Kinases. The resultant phosphoinositides act as selective membrane docking sites for signal transduction proteins with diverse $\mathrm{PH}$ domains. Phosphorylated inositols are released as second messengers by enzymatic cleavage of the phosphoinositides. 